\title{
KiVa kiusamisvastase programmi prooviuuring Eestis: kaheaastase klaster-randomiseeritud kontrollkatse tulemused
}

\author{
Kristiina Treial $^{\text {ab1 }}$ \\ ${ }^{a}$ Tartu Ülikooli haridusteaduste instituut \\ ${ }^{b}$ SA Kiusamisvaba Kool
}

\begin{abstract}
Annotatsioon
Kiusamine on Eesti koolides levinud ja ühiskondlikult kulukas probleem, mille tagajärjel kahjustub ohvrite vaimne ja sotsiaalne tervis, väheneb akadeemiline edukus ning suureneb koolist väljalangemise risk. Koolide ülesanne on kiusamist tõkestada. 2013. aastal käivitus Eestis KiVa programmi kohandamise ja katsetamise projekt, mille raames tehti kontrollkatse 20 katsekoolis ja 19 kontrollkoolis. Eesmärk oli kirjeldada kohandatava KiVa kiusamisvastase programmi mõju kaheaastase klaster-randomiseeritud kontrollkatse abil. Olweuse kiusaja/ohvri küsimustikule vastas õppeaasta alguses 5090, esimese õppeaasta lõpus 5814 ning teise õppeaasta lõpus 3993 1.-6. klassi õpilast. Uurimistulemustest selgus, et ühe õppeaasta jooksul vähenes KiVa koolides kiusamise ohvrite hulk oluliselt võrreldes nii baastaseme kui ka kontrollkoolide tasemega. Seevastu kiusajate hulga keskmised protsendid esimesel aastal oluliselt ei vähenenud.
\end{abstract}

Võtmesõnad: koolikiusamine, kiusaja, ohver, tõenduspõhine kiusamisvastane programm, randomiseeritud kontrollkatse

\section{Sissejuhatus}

Kiusamine on laialt levinud ja universaalne probleem. Kõige rohkem on kiusamist käsitletud kooli kontekstis (Olweus, 2013). Aastakümnete jooksul on tehtud rohkelt uuringuid kiusamise olemuse, põhjuste ja tagajärgede paremaks mõistmiseks ning arendatud tavasid ja programme, mille abil kiusamist vähendada (Rigby \& Smith, 2011). Ometi on kiusamine koolides laialt levinud, keskmiselt iga kümnes õpilane kannatab kiusamise all 
(Olweus, 2013). Eesti koolides on kiusamist teiste riikidega võrreldes suhteliselt palju, kiusamise all kannatajate hulk on üle 20\% (nt Chester et al., 2015; Craig et al., 2009; Currie et al., 2012), kuid tegutsemine eesmärgiga vähendada kiusamist on olnud üsna kaootiline. Chesteri ja tema kolleegide (2015) kokkuvõtted kooliealiste laste tervisekäitumise (HBSC) uuringutest aastatel 2002-2010 näitavad, et Eestis sel perioodil ohvrite ja kiusajate levimuses olulist muutust ei toimunud: 11-15aastaste poiste hulgas oli ohvreid üle 20\%, tüdrukute hulgas $15-20 \%$. Kõige suuremas riskigrupis paistavad olevat 11 aastased poisid, kes ligi $27 \%$ ohvritega ja $21 \%$ kiusajatega on HBSC 2009/2010. aasta uuringus osaleva üle 40 riigi hulgas teisel kohal (Currie et al., 2012). Eestis on kiusamist rohkem poiste ja nooremate õpilaste hulgas, vanuse kasvades kiusamise sagedus väheneb (ibid.). Sarnastele tulemustele on oma kokkuvõtvas ülevaates osutanud ka Kõiv (2009). Praeguseks on Eestis võetud selge suund vähendada tõenduspõhise tegevuse kaudu vägivalda, sh kiusamist (vt vägivalla ennetamise strateegia aastateks 2015-2020), kuid korrektse disainiga mõju-uuringuid haridusvaldkonnas kasutusel olevate sekkumisviiside kohta tehtud ei ole.

Tõhusaimaks kiusamise vähendamise viisiks peetakse süstemaatiliste tõenduspõhiste programmide kasutuselevõttu koolikeskkonnas (Evans, Fraser, \& Cotter, 2014; Farrington \& Ttofi, 2009). Eestis pole seda tüüpi kooliterviklikke kiusuennetusprogramme varem kohandatud ega nende tulemuslikkust hinnatud. Praegune artikkel keskendub KiVa kiusamisvastase programmi kohandamisele ja katsetamisele Eesti koolides. Eesmärk on kirjeldada KiVa programmi mõju kaheaastase katseperioodi jooksul tehtud randomiseeritud kontrollkatse ${ }^{2}$ (randomised control trial) abil.

\section{Kiusamise olemus ja käsitlused}

Kiusamine koolikeskkonnas on pälvinud paljude uurijate tähelepanu, sest järjest enam koguneb tõendeid selle kohta, et kiusamine avaldab kahjulikku lühi- ja pikaajalist mõju nii ohvrile kui ka kiusajale (Olweus, 2013). Selle tagajärjel kahjustub ohvrite vaimne ja sotsiaalne tervis (Arseneault, Bowes, \& Shakoor, 2010; Hawker \& Boulton, 2000), väheneb akadeemiline edukus ning suureneb koolist väljalangemise risk (Nakamoto \& Schwartz, 2010). Kiusajatel täheldatakse pikaajalise tagajärjena neli korda suuremat kuritegeliku käitumise riski kui mittekiusajatel (Olweus, 2013). Kahjust puutumata ei jää ka kõrvalseisjad: võrreldes nendega, kes ei ole kiusuga kokku puutunud, on kõrvalseisjatel täheldatud kõrgemat ärevuse ja depressiivsuse

Järgmistes peatükkides kasutatakse termini randomiseeritud kontrollkatse tähistamiseks lühendit $R K K$. 
taset, aga ka suuremat vaenulikkust ja uimastite tarbimise riski (Rivers, Poteat, Noret, \& Ashurst, 2009). Arvestatavatele isiklikele kannatustele ja pereliikmete probleemidele lisaks toob kiusamine endaga kaasa suuri ühiskondlikke kulusid (Olweus, 2013). Kiusamise näol on tegemist probleemiga, millel on rohkelt nii otseseid kui ka kaudseid lühi- ja pikaajalisi tagajärgi, mis koormavad peale haridussüsteemi ka tervishoiu- ja õigussüsteemi. Sourander jt (2007) on näidanud, et nii endised ohvrid kui ka kiusajad on sageli tervishoiu- ja sotsiaalabisüsteemides n-ö ületarbijad. Seega on riiklikult tähtis pöörata tähelepanu kiusamise ennetusele ja võimalikult varajasele peatamisele.

Kiusamise olemuse mõistmine on tõhusa ennetus- ja sekkumistegevuse alus. Tavaelus kasutatakse kiusamise mõistet oluliselt laiemas tähenduses kui teaduslikes käsitlustes (Olweus, 1993, 2013). Kiusamist kiputakse segi ajama ühekordsete tülide, kakluste, konfliktide ja arusaamatustega, mis on inimsuhetes üsnagi sagedased. Kiusamine on aga palju keerukam ja selgepiirilisem nähtus, kuigi vaidlused täpse definitsiooni üle kestavad tänapäevani (nt Volk, Dane, \& Marini, 2014). Enim kasutatakse Olweuse (1993, 2013) sõnastatud definitsiooni, milles sisalduvad kiusamisele iseloomulikud kolm tunnust: kiusamine on tahtlik ja korduv teist inimest kahjustav (agressiivne) käitumine, mida kannatajal on jõudude ebavõrdsuse tõttu raske peatada. Sarnased kiusamiskäitumist defineerivad tunnused on välja joonistunud ka Eesti laste seas tehtud uuringutes (nt Kõiv, 2006, 2009). Just kiusamise tahtlikkus, korduvus ja jõudude ebavõrdsus on need tingimused, mis toovad kaasa tõsise kahju (Olweus, 2013).

Kiusamist kui mitmetahulist sotsiaaldünaamilist nähtust on mõtestatud mitmete teooriate kaudu alates sotsiaalse kapitali ja organisatsioonikultuuri teooriatest (vt Evans \& Smokowski, 2015) kuni kiusamisega seotud rollide käsitluseni (participant roles approach, Salmivalli, Lagerspetz, Björkqvist, Österman, \& Kaukiainen, 1996). Rollikäsitluse järgi on kiusamisel oma funktsioon ja sotsiaalne arhitektuur. Kiusajad taotlevad kiusamiskäitumise abil võimu ja kõrgemat sotsiaalset positsiooni, mille nad uuringute järgi ka saavutavad. Seetõttu ongi kiusamine nii levinud ja püsiv. Võtmeroll on kõrvaltvaatajatel. Salmivalli (2014) on erinevatele uuringutele toetudes kokku võtnud, et kiusamine vajab publikut ja seda pakuvad kas vaikivad või kaasa aitavad kõrvalseisjad (kiusaja kannustajad, assistendid, kõrvalejääjad, vt Salmivalli et al., 1996).

Kiusamist saavad potentsiaalselt peatada kaitsja rolli astuvad kaaslased, kuid neid on vähe (Salmivalli et al., 1996). Vaikimisega toetatakse kiusamist isegi siis, kui õpilasel endal on tegelikult kiusamist taunivad hoiakud. Salmivalli (2014) põhjendab seda uuringutele toetudes kolmel viisil. Esiteks, 
kiusajaid tajutakse sageli populaarsetena ja ohvri kaitseks väljaastumist ohuna kaitsja enese staatusele. Teiseks, grupis võib kujuneda „pluralistlik eiramine", mille korral ei astuta kiusaja käitumisele vastu, kuna õpilased arvavad (ekslikult), et kõik teised kiidavad toimuva heaks. Kolmas põhjus võib peituda kiusajate valikulises agressiivsuses: nad valivad endale haavatavad ja nõrgemal positsioonil olevad ohvrid, suurendades nii edu tõenäosust ja vähendades teiste heakskiidu kaotamise riski (ibid.). Samas näitavad uuringud, et ohvrid, kellel on klassikaaslaste hulgas toetajaid ja kaitsjaid, kannatavad kiusamise negatiivse mõju all vähem (Sainio, Veenstra, Huitsing, \& Salmivalli, 2010). Klassides, kus ohvrit kaitsvaid ja kiusamist taunivaid õpilasi on rohkem, on kiusu vähem (Nocentini, Menesini, \& Salmivalli, 2013). Ka õpetajate roll vajab siin esiletoomist - klassides, kus õpilased tajuvad selgelt õpetajate taunivat suhtumist kiusamisse ja näevad nende pingutusi kiusamise lõpetamiseks, on vähem kiusamist (Saarento, Kärnä, Hodges, \& Salmivalli, 2013). Osalejate rollide teadvustamine kiusamise vallandamisel, säilitamisel ja mõjude kujunemisel on võimaldanud kavandada tõhusaid sekkumisprogramme (Saarento, Boulton, \& Salmivalli, 2015; Saarento \& Salmivalli, 2015; Salmivalli, 2014) ning sellele toetub ka KiVa kiusamisvastane programm (Salmivalli \& Poskiparta, 2012a, 2012b). Selles programmis on peale ohvrite ja kiusajate eraldi tähelepanu pööratud just kõrvaltvaatajate hoiakutele ja käitumisele ning programmi tegevused seavad selged ülesanded ópetajatele. Saarento ja tema kolleegide (Saarento et al., 2015) uurimuses on näidatud, et üks oluline mehhanism, mille kaudu KiVa programm kiusamist vähendab, on õpilaste tajutud kaitsmiskäitumise suurenemine, samuti on kiusamise vähendamise seisukohalt tähtis, et õpilased tajuksid õpetajate tehtavaid pingutusi.

\section{Kiusamise vähendamine koolides}

Kiusamine sisaldab otseseid riske õpilaste tervisele, seetõttu on kiusamise vähendamine oluline osa terviseedendusest (Chalamandaris \& Piette, 2015; Hodgins, 2008). Lisaks on koolidel kohustus tagada õpilaste turvalisus koolipäeva jooksul (Põhikooli- ja gümnaasiumiseadus, 2010). Kiusuennetuses levib algatusi ja tegutsemisviise, mille mõju ei ole kas üldse või metodoloogiliselt usaldusväärselt hinnatud. Samas leidub selliseid programme, millel on tugev teaduslik alus ja kontrollitud tulemuslikkus, kuid nende tõhusus kiusamise vähendamisel on mõju-uuringute järgi väga ebaühtlane (Evans et al., 2014; Farrington \& Ttofi, 2009; Merrell, Gueldner, Ross, \& Isava, 2008; Ttofi \& Farrington, 2011). Raskused programmide mõju korduval demonstreerimisel võivad tuleneda programmi usaldus- 
väärse rakendamise ebaõnnestumisest (implementation failure), programmi aluseks oleva teooria ebapiisavusest või mittetoimimisest (theory failure) või suutmatusest käivitada muutuseks vajalikke mehhanisme uutes kontekstides ning probleemidest uuringu läbiviimisel (evaluation failure) (Katz et al., 2013).

Ennetus- ja sekkumistegevuste puhul räägitakse aina enam tõenduspõhistest tegevustest ja programmidest (Ferrer-Wreder, Sundell, \& Mansoory, 2012). Tõenduspõhiseks peetakse ennekõike neid sekkumisviise, millel on tugev teoreetiline ja uuringutele toetuv alus (põhjendus, miks need tegevused võiksid anda oodatud tulemusi) ning mille mõju ja tõhusus on leidnud kinnitust usaldusväärsetes ja rangetele nõuetele vastavates uurimustes (nt Blueprints Programs, s.a). Tõenduspõhised tegevused on praktikute kasutatavad tegevused, mille kasu on uuringutega tõestatud, seevastu programmid on nn tuumtegevustest koosnevad süsteemid, mille koosmõju on eksperimentaalselt hinnatud kindlas kontekstis (Fixsen et al., 2005, lk 26). Tõenduspõhistest programmidest on enim tunnustust leidnud Olweuse kiusuennetusprogramm ja KiVa kiusamisvastane programm (Ttofi \& Farrington, 2011; Blueprints Programs, s.a).

\section{Tõenduspõhiste programmide kohandamine}

Tõenduspõhiste programmide loomine on ressursi- ja ajamahukas tegevus, seetõttu kasutatakse aina enam võimalust kohandada uute kultuuride tarbeks programme ja tegevusi, mille tõhusust on mõju-uuringutega juba tõendatud (Ferrer-Wreder et al., 2012). Kohandamise teeb keeruliseks asjaolu, et tõendid programmi mõju kohta on saadud kindlas kontekstis ja programmi tuumtegevuste rakendamisel. Tõenduspõhise programmi kohandamise peamiseks raskuseks on programmi terviklikkuse säilitamine alusteooriat ja tuumtegevusi arvestades (fidelity) ning nende mõlema mõju tagamine uues kontekstis (ibid.).

Uude konteksti toodud, teise keelde tõlgitud ja sisuliselt kohandatud programmi puhul on vaja uuesti hinnata selle mõju. Tõenduspõhise programmi kohandamiseks on välja pakutud mitmeid mudeleid. Peamiselt hõlmavad need võrgustikusisest koostööd algsete arendajate ja uude kultuuri kohandajate vahel, sammsammulist liikumist programmi toimemehhanismide kultuurilise sobivuse suunas, materjalide tõlkimist, uues kultuuris rakendamise valmiduse saavutamist, esialgseid uuringuid, mille eesmärk on hinnata täiendavat kohandamisvajadust, ja lõpuks programmi mõju ranget hindamist uues kultuuris (Castro, Barrera, \& Holleran Steiker, 2010; Ferrer-Wreder et al., 2012). Kui kohandatud programmi katsetused 
ei anna oodatud tulemusi, tasub otsida põhjusi mõju-uuringu disaini erinevustest, katse- ja kontrollgrupi moodustamise ning kvaliteedi probleemidest, programmi mittetäielikust rakendamisest, kultuurierinevustest ja kindlasti ka kehvast kohandamisest (Ferrer-Wreder et al., 2012).

\section{KiVa kiusamisvastane programm ja selle kohandamine Eestis}

KiVa kiusamisvastase programmi aluseks on tänapäevane teaduslik kiusamise olemuse käsitlus, mille tõhusus on tõestatud põhjalike ja suuremahuliste kontrollkatsetega ning üle Soome korraldatud uuringuga (Salmivalli \& Poskiparta, 2012a). KiVa (akronüüm soomekeelsest sõnaühendist kiusaamista vastaan 'kiusamise vastu', ka 'kena') on välja töötatud aastatel 2006-2009 Turu Ülikoolis Soome haridus- ja kultuuriministeeriumi ülesandel. Aastatel 2007-2009 viidi läbi programmi mõjude hindamise RKKd ning aastal 2009 laienes programm koolidesse üle Soome. Praeguseks on KiVa programmiga liitunud ligi 90\% Soome üldhariduskoolidest (vt lähemalt KiVa International, s.a; Salmivalli \& Poskiparta, 2012b).

KiVa programmi eesmärk on lõpetada kiusamisjuhtumid, ennetada uusi kiusamisjuhtumeid ning vähendada kiusamise negatiivset mõju (Salmivalli \& Poskiparta, 2012b). See programm on kooli igapäevaelu strateegiline osa, mis hõlmab kogu kooliperet (õpilasi, personali, lapsevanemaid) ja tugineb kiusamises osalejate rollide käsitlusele (Salmivalli, 2014; Salmivalli et al., 1996; Salmivalli \& Poskiparta, 2012b). KiVa programmi edukuse võtmeks võib pidada kiusamise vähendamise seisukohalt tõhusate tegevuste koondamist ühte süsteemi. Sellist lähenemisviisi programmide koostamisel on hiljem metaanalüüside põhjal soovitanud ka Farrington ja Ttofi (2009). Programm sisaldab konkreetseid tegevusi kiusu ennetamiseks ja kiusamisjuhtumite lahendamiseks. Kõigile mõeldud ennetustegevused hõlmavad koolis kiusamise vähendamise (KiVa) meeskonna moodustamist ja koolitamist, teadlikkust suurendavaid kohtumisi, materjale personalile ja lapsevanematele, KiVa tunde I-III kooliastmes, virtuaalset tuge täiskasvanutele ja õpikeskkonda õpilastele ning KiVa sõnumit kandvaid elemente koolimajas (vt täpsemalt KiVa International, s.a; Salmivalli \& Poskiparta, 2012b). Ettetulevate kiusamisjuhtumite lahendamisel rakendab kooli KiVa meeskond koostöös klassijuhatajatega kahte tõendatud tõhususega juhtumite lahendamise mudelit, mis hõlmavad mitmeid selgelt struktureeritud ja eesmärgistatud individuaalseid vestlusi, grupikohtumisi ning järeltegevusi (Garandeau, Poskiparta, \& Salmivalli, 2014). Igal õppeaastal vastavad õpilased ja personaliliikmed küsitlustele eesmärgiga saada tagasisidet olukorra kohta oma koolis. Programmi arendajad toetavad koole infomaterjalidega 
ja KiVa rakendamise kvaliteeti parandavate soovitustega ning korraldavad KiVa koolidele konverentse (Salmivalli \& Poskiparta, 2012b).

2012. aastal asutati Eestis sihtasutus Kiusamise Vastu (praegu SA Kiusamisvaba Kool, vt Kiusamisvaba Kool, s.a) ning hakati koostöös Turu Ülikooliga kohandama KiVa programmi elemente Eesti koolidele. Selleks analüüsiti esmalt programmi sobilikkust Eesti konteksti ja haridussüsteemi ning seejärel tõlgiti ja modifitseeriti programmi peamised elemendid. Sellesse protsessi oli kaasatud rühm hariduse ja suhtlemiskoolituse valdkonna spetsialiste. Katseperioodil kohandati ja vajaduse korral ka täiendati programmi elemente, kuid osa arendustegevusi on veel pooleli. Seejuures lähtuti põhimõttest, et esmalt katsetatakse võimalikult originaalilähedast programmi, seejärel täiendatakse programmi elemente uuringu ja kogutud tagasiside põhjal, et see vastaks võimalikult täpselt Eesti vajadustele ja olemasolevatele ressurssidele. Lühiülevaade KiVa programmi elementidest ja nende kohandamisest Eesti koolidele on esitatud tabelis 1.

Kõigepealt kohandati KiVa tunnid I ja II kooliastmele, kuna programmi tõhususe näitajad III kooliastmes olid kasinad (Kärnä et al., 2011b; Yeager, Fong, Lee, \& Espelage, 2015). Esimese katsetamisaasta jooksul selgus, et tundides kasutatavad Soome õppevideod ei kõneta Eesti lapsi, seetõttu otsustati toota Eesti omad óppevideod. Programmi virtuaalsest toest on seniajani ressursipuuduse tõttu kohandamata arvutimängud I ja II kooliastmele. Erinevalt Soomes kord aastas toimuvatest KiVa päevadest korraldab SA Kiusamisvaba Kool KiVa koolide meeskondadele kogemuspõhiseid kohtumisi kaks korda õppeaastas. Esialgu oli tihedamate kohtumiste taga soov saada kvalitatiivset tagasisidet programmi katsetamise kohta, praeguseks on koolide KiVa meeskondade liikmed oma arvamustes rõhutanud kogemuspäevade väärtust kolleegitoe ja täienduskoolituse võimalusena.

KiVa programmi rakendamise katseetapina korraldati 2013. aasta suvel KiVa koolide meeskondadele koolitusi ning sügisel selgitati õpilasküsitluse abil välja baastase. Esimesel õppeaastal rakendati intensiivselt KiVa tunde kõigis I ja II kooliastme klassides, teisel óppeaastal jätkati KiVa tundide andmist ühel korral I kooliastmes ja ühel korral II kooliastmes, tavapäraselt 1. ja 4. klassis. Ülejäänud klassides käsitleti KiVa teemasid meeldetuletavalt ning lõimituna klassijuhataja- ja ainetundidesse. Nii esimesel kui ka teisel katsetamisaastal korraldati õpilastele, personalile ja lapsevanematele mitmesuguseid informeerimistegevusi, korrapidajaõpetajad kandsid vesti ning KiVa meeskond lahendas ettetulnud kiusamisjuhtumeid. Teise katseaasta kevadel alustati ootejärjekorras olnud kontrollkoolide ettevalmistamist ja koolitamist eesmärgiga rakendada KiVa programmi 2015/2016. óppeaastal. 
Tabel 1. KiVa programmi elemendid ja nende kohandamine Eestis

\begin{tabular}{|c|c|c|c|}
\hline \multirow[b]{2}{*}{$\begin{array}{l}\text { KiVa programmi elemendid Soomes } \\
\text { (Salmivalli \& Poskiparta, 2012b) }\end{array}$} & \multicolumn{3}{|c|}{$\begin{array}{l}\text { KiVa programmi } \\
\text { elemendid Eestis }\end{array}$} \\
\hline & 2013 & 2014 & 2015 \\
\hline KiVa meeskonna koolitus & + & + & + \\
\hline KiVa klassijuhataja koolitus & & $+^{2}$ & $t^{2}$ \\
\hline KiVa tunnid I kooliastmele & + & + & + \\
\hline KiVa tunnid II kooliastmele & + & + & + \\
\hline \multicolumn{4}{|l|}{ KiVa tunnid III kooliastmele } \\
\hline \multicolumn{4}{|l|}{ KiVa arvutimäng 1} \\
\hline \multicolumn{4}{|l|}{ KiVa arvutimäng 2} \\
\hline KiVa tundide esitlused ja videod & $t^{3}$ & $t^{3}$ & $t^{3}$ \\
\hline KiVa juhtumite lahendamise mudelid & + & + & + \\
\hline KiVa plakatid & + & + & + \\
\hline KiVa vestid korrapidajaõpetajatel & + & + & + \\
\hline $\begin{array}{l}\text { Lapsevanemate infokohtumine „Tagasi kooli õhtu” ja KiVa } \\
\text { infoleht }\end{array}$ & + & + & + \\
\hline Lapsevanemate miniõpik (paberil, veebis) & & + & + \\
\hline KiVa sisekoolitus ja infokoosolek personalile & + & + & + \\
\hline Õpilasküsitlus & + & + & + \\
\hline Personali küsitlus & + & + & + \\
\hline KiVa koolide konverentsid & $\begin{array}{c}2 \text { korda } \\
\text { aastas }\end{array}$ & $\begin{array}{c}2 \text { korda } \\
\text { aastas }\end{array}$ & $\begin{array}{c}2 \text { korda } \\
\text { aastas }\end{array}$ \\
\hline
\end{tabular}

Märkused. ${ }^{1}$ - allikas: SA Kiusamisvaba Kool. ${ }^{2}$ - 2014. aastal töötati välja Eesti oma veebikoolitus klassijuhatajatele. ${ }^{3}$ - esialgu eestikeelsete subtiitritega Soome õppevideod, 2015. aastast Eesti oma videod.

\section{Uurimuse eesmärk ja uurimisküsimused}

Uurimus keskendub KiVa kiusamisvastase programmi kohandamise käigus tehtud esmasele katsetamisele Eesti koolides. Toetudes Soomes (Kärnä et al., 2011a, 2011b) ja Walesis (Hutchings \& Clarkson, 2015) saadud positiivsetele tulemustele, oletati, et Eesti koolide tarbeks kohandatud KiVa programmi tuumtegevuste katsetamise tulemusena väheneb nii kiusajate kui ka ohvrite levimus oluliselt juba esimese õppeaasta lõpuks ning sama trend 
jätkub ka teisel õppeaastal. Samas oli uuringu tegija valmis võimaluseks, et positiivne muutus ei pruugi ilmneda, kuna programmi elemente ei ole veel piisavalt kohandatud (sellele võimalusele osutavad teoreetilises ülevaates ka Ferrer-Wreder et al., 2012).

Uurimuse eesmärk on kirjeldada KiVa programmi tulemuslikkust programmi kaheaastase katsetamisperioodi jooksul tehtud RKK abil. Lisaks sooviti kirjeldada kiusamise levimust valimis ning võimalikke soolisi ja vanuselisi erinevusi. Uuringu käigus otsiti vastuseid järgmistele küsimustele. 1. Millised on valimisse sattunud koolides ohvrite ja kiusajate levimuse baastaseme ning järelhindamiste näitajad?

2. Milliseid muutusi võib täheldada programmi katsetavates koolides kiusajate ja ohvrite levimuse näitajates aasta ja kaks aastat pärast programmiga alustamist ning millised erinevused ilmnevad võrdluses kontrollkoolidega?

Esmase tulemusena oodati programmi rakendamise järel KiVa koolides oluliselt väiksemat ohvrite ja kiusajate levimust võrreldes nii baastaseme kui ka kontrollkoolide tasemega.

\section{Meetod}

\section{Uuringu disain}

KiVa kiusamisvastase programmi kohandamise ja katsetamise projekti raames hindas artikli autor programmi võimalikku mõju kiusamise levimusele kahe aasta vältel, kasutades selleks klaster-RKKd. See sisaldab juhuvalikuga moodustatud katse- ja kontrollgruppi ning mitut mõõtmishetke. RKK disaini peetakse sekkumise või programmi mõju hindamisel üheks rangemaks ja suurima usaldusväärsusega uuringustrateegiaks (Blueprints Programs, s.a; Chalamandaris \& Piette, 2015). Praeguses uuringus oli katseja kontrollgruppi jaotamise ühikuks ehk klastriks kool tervikuna. Kuna KiVa programm sisaldab tegevusi kogu koolile, selles ei saa osaleda ainult üks õpilane või üks klass, siis oli kooli kui terviku võtmine randomiseerimisühikuks ainuvõimalik lahendus (vt ka Campbell, Piaggio, Elbourne, \& Altman, 2012). Andmete kogumisel kasutati kolmesammulist skeemi: kiusamise baastaseme hindamist programmi alguses (septembris ja oktoobris 2013), taseme hindamist esimese õppeaasta lõpus (mais 2014) ja teise õppeaasta lõpus (mais 2015).

Klaster-RKK etappide ajaline järjestus on kujutatud joonisel 1 toodud voogdiagrammil. Kuna siinne uurimus tuli sobitada laiema KiVa kiusamisvastase programmi kohandamise ja katsetamise projekti raamidesse, on 
selles mitmeid erinevusi võrreldes RKK disaini heade tavadega (vt Campbell et al., 2012). Projektiga oli kindlaks määratud KiVa programmi katsetama hakkavate koolide arv - kuni 20 kooli. Projekti tegevuste ajakava tõttu küsiti lapsevanematelt informeeritud nõusolekut ja hinnati baastaset alles pärast randomiseerimist.

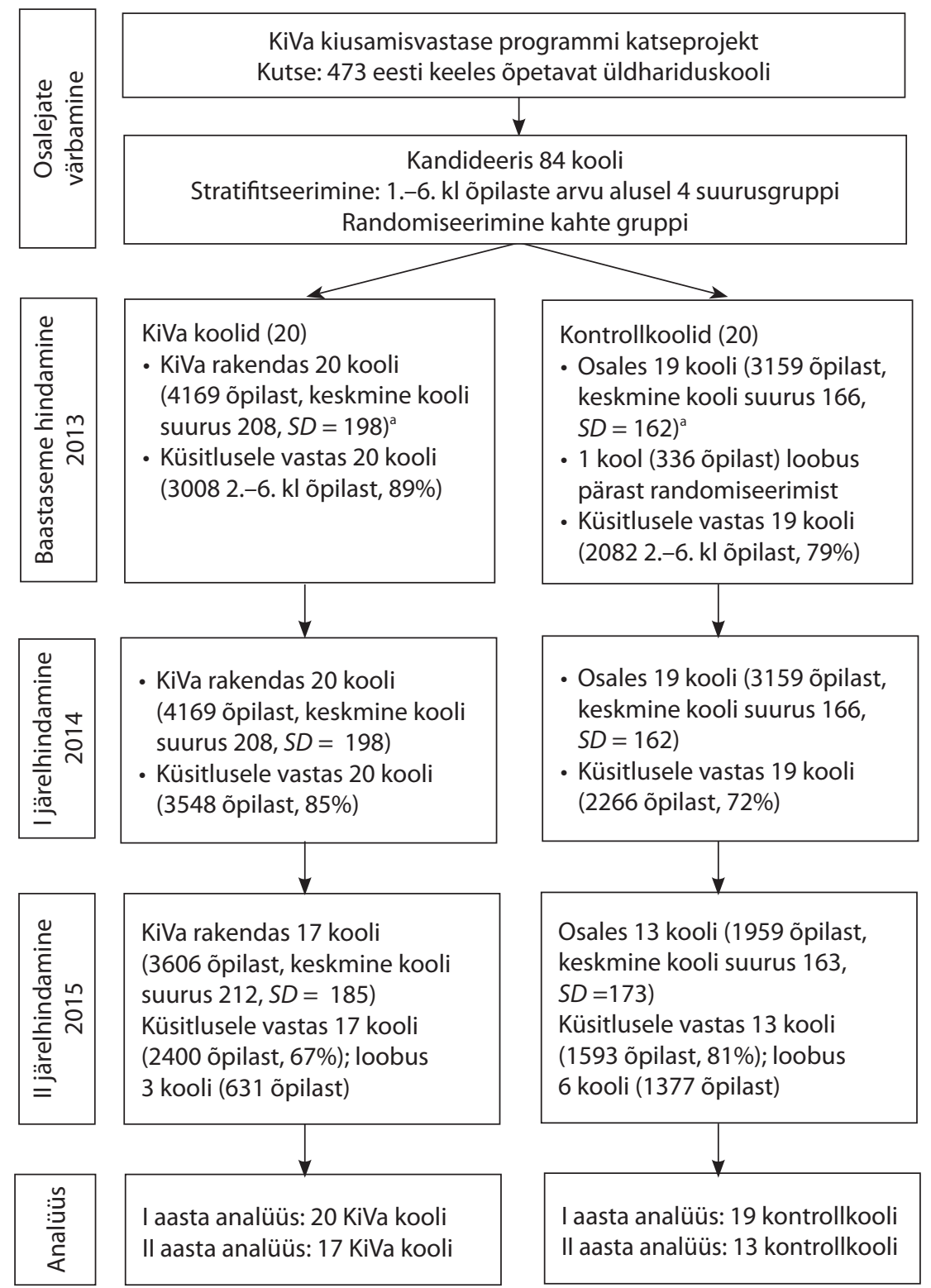

Joonis 1. Klaster-RKK voogdiagramm ( ${ }^{a}$ - osalevate koolide koguvalimi suurus EHISe andmebaasi järgi) 


\section{Valim}

Uuringu valim koosnes 20 KiVa programmi katsetanud koolist ja 19 kontrollkoolist. Kontrollkoolid olid nn ootejärjekorras olevaks kontrollgrupiks, kes jätkasid esialgu tegutsemist tavapärasel viisil ja kellele pakuti eelisjärjekorda KiVa programmiga liitumiseks pärast katseprojekti lõppemist 2015. aastal. Ülevaade katseprojekti kaasatud koolidest eri etappidel on toodud klaster-RKK voogdiagrammil (joonis 1).

Valimi moodustamiseks saadeti kõigepealt informeeriv e-kiri ja üleskutse osaleda katses kõigile eesti keeles ja tavaõppekava järgi õpetavatele üldhariduskoolidele, kus õppetöö toimus vähemalt I ja II kooliastmes (473 kooli). Üleskutsele vastas positiivselt 84 kooli. Seejärel rakendati soovi avaldanud koolide piiratud randomiseerimist. Et valim oleks tasakaalustatud, st koosneks eri suurusega üldhariduskoolidest, viidi esmalt läbi stratifitseerimine kooli suuruse alusel. Koolid jaotati EHISes esitatud I ja II kooliastme õpilaste arvu põhjal moodustatud kvartiilidest lähtudes nelja suurusgruppi: väga väikesed, väikesed, keskmised ja suured koolid. Igast suurusgrupist loosis uurija assistent viis kooli katsetama KiVa programmi ja viis kooli kontrollkooliks, nimetades pimesi numbreid 1-21ni (igas suurusgrupis oli 21 kooli). Mõlemasse gruppi randomiseeriti kokku 20 eri suurusega kooli Eesti eri piirkondadest. Üks suur kontrollkool loobus osalemast vahetult enne uuringu algust, seetõttu jäi kontrollgruppi 19 kooli. Teise õppeaasta alguses loobus prooviuuringus osalemisest veel kolm katse- ja viis kontrollkooli. Ülevaade õpilaste arvudest gruppides ja mõõtmishetkedel on esitatud tabelis 2 .

Tabel 2. Analüüsi kaasatud koolide ja õpilaste arvud KiVa ja kontrollgrupis kolme õpilasküsitluse arvestuses

\begin{tabular}{l|c|c|c}
\hline & $\begin{array}{c}2013 \text { (2.-6. klass) } \\
20 / 19 \text { kooli }\end{array}$ & $\begin{array}{c}2014 \text { (1.-6. klass) } \\
20 / 19 \text { kooli }\end{array}$ & $\begin{array}{c}2015 \text { (1.-6. klass) } \\
17 / 13 \text { kooli }\end{array}$ \\
\hline KiVa grupp & 3008 & 3548 & 2400 \\
\hline 1. kl tüdrukuid/poisse & & $301 / 351$ & $231 / 225$ \\
\hline 2.-3. kl tüdrukuid/poisse & $599 / 674$ & $598 / 649$ & $416 / 446$ \\
\hline 4.-6. kl tüdrukuid/poisse & $855 / 880$ & $829 / 821$ & $513 / 569$ \\
\hline Kontrollgrupp & 2082 & 2266 & 1593 \\
\hline 1. kl tüdrukuid/poisse & & $178 / 181$ & $149 / 143$ \\
\hline 2.-3. kl tüdrukuid/poisse & $520 / 454$ & $461 / 414$ & $301 / 284$ \\
\hline 4.-6. kl tüdrukuid/poisse & $583 / 525$ & $543 / 489$ & $388 / 328$ \\
\hline
\end{tabular}




\section{Mõõtevahendid}

Andmete kogumisel kasutati Soomes Turu Ülikoolis KiVa programmi arendajate välja töötatud õpilasküsitluse metoodikat. Tegemist on anonüümse veebipõhise küsitlusega 1.-6. klassi õpilastele ning see sisaldab mitmeid alaosi alates enesekohastest hinnangutest kiusamiskäitumise ja kiusamise all kannatamise sagedusele kuni kiusamisega seotud hoiakute ning akadeemilise motivatsioonini. Siinse artikli autor ja tema assistent tõlkisid ja kohandasid õpilasküsitluse küsimused eesti keelde. Kohandamise käigus tõlkisid nii autor kui ka assistent esmalt kõik küsimused eraldi. Seejärel arutati läbi tõlgetes ilmnenud üksikud erinevused ning katsetati küsimuste mõistmist ühe 7aastase poisi peal. Tõlge hinnati sobilikuks ja lisakohandusi ei tehtud.

Siinses artiklis käsitletakse ainult kiusamise all kannatamise ja teiste kiusamise sageduse hinnangute põhjal leitud ohvrite ja kiusajate protsente, mille väljaselgitamiseks nii baastasemel kui ka esmasel ja teisel järelhindamisel kasutati kaht Olweuse kiusaja/ohvri küsimustiku üldistatud küsimust (Olweus Bully/Victim Questionnaire/global items, OBVQ; Olweus, 1996, viidatud Kärnä et al., 2011a järgi). OBVQ on üks enim kasutatud vahendeid, mis võimaldab hinnata kiusamist ja ohvriks olemist, ning seda on Eestis varem rakendatud ka mitmes suures rahvusvahelises uuringus, nt kooliealiste laste tervisekäitumise uuringus (HBSC), millesse on praeguseks kaasatud üle 40 riigi Euroopast ja Põhja-Ameerikast.

Globaalne OBVQ koosneb kahest küsimusest: „Kui tihti on Sind koolis viimase paari kuu jooksul kiusatud?” ja „Kui tihti oled koolis kedagi kiusanud paari viimase kuu jooksul?". Küsimustele eelneb seletus selle kohta, mis on ja mis ei ole kiusamine (vt ka Olweus, 2013), ning vahetult enne iga küsimust esitatakse veel kord kiusamise lühidefinitsioon: „Kiusamine on see, kui üks õpilane põhjustab meelega ja korduvalt teisele õpilasele halba enesetunnet", ning palutakse mõelda enda paari viimase kuu kogemustele. Õpilased vastavad 5punktisel skaalal, kus $0=$ üldse mitte, $1=1-2$ korda, $2=2-3$ korda kuus, $3=$ umbes kord nädalas ja $4=$ mitu korda nädalas. OBVQ kahe üldistatud küsimuse kasutamist on peetud usaldusväärseks ja sobilikuks viisiks hinnata kiusamise ja selle all kannatamise levimust (prevalence) nii kooli kui ka riikide tasandil (Solberg \& Olweus, 2003). Ilmnenud on tugevad seosed üldiste hinnangute ja kiusamise eri vormidele antud hinnangute vahel ning kaaslaste antud hinnangutega (Kärnä et al., 2011a; Solberg \& Olweus, 2003). Eestis OVBQ psühhomeetrilisi omadusi seni hinnatud ei ole. 


\section{Protseduur}

Pärast kontroll- ja katsekoolideks loosimist küsiti programmis osalevate koolide 1.-6. klassi õpilaste vanematelt kirjalik nõusolek nende lapse osalemiseks KiVa programmi katsetamise uuringus. Kuigi RKKde jaoks soovitatakse võtta nõusolekud enne randomiseerimist (vt Campbell et al., 2012), tehti seda praegusel juhul pärast randomiseerimist. Sellise järjestuse tingis kohandamis- ja katsetamisprojekti pingeline ajakava ning tegevuste ajastus õppeaasta jooksul, mistõttu ei olnud võimalik võtta nõusolekuid enne randomiseerimist. Lisaks randomiseeriti kohandamis- ja katsetamisprojektis määratud katsegrupi suuruse tõttu ainult osa soovi avaldanud koolidest, seega ei olnud mõttekas koguda nõusolekuid enne, kui oli täpselt teada, mis koolid uuringusse kaasatakse. Et valim oleks võimalikult esinduslik, kasutati opt-out-protseduuri, mille kohaselt võisid uuringus osaleda kõik lapsed, kelle vanem ei väljendanud nõusolekulehel (oma allkirjaga) selget keeldumist. Projekti alguses oli KiVa koolides keeldujaid 5\% ja kontrollkoolides 6\%. Järgmise õppeaasta alguses võeti lisanõusolekud uute 1. klasside lapsevanematelt. Nõusolekukirjad edastasid lapsevanematele ja kogusid kokku klassijuhatajad. Uuringus mitteosalevatele õpilastele korraldasid klassijuhatajad küsimustiku täitmise ajaks alternatiivse tegevuse. Klassijuhatajatele tutvustati kirjalikult uuringu protseduuri.

Õpilased täitsid anonüümse küsimustiku 2-3 nädala jooksul koolipäeva ajal kooli arvutiklassis, logides uuringukeskkonda sisse oma kooli kasutajanime ja parooliga. Ühegi õpilase nime ei küsitud. Klassijuhatajad lugesid vajaduse korral noorematele õpilastele küsimustiku tekste ette, kuid vastuse pidid lapsed ise valima. Kuna kiusamiskogemused on emotsionaalselt tundlik valdkond ja sotsiaalselt soovitavate vastuste andmise risk on suur, julgustab anonüümne veebikeskkond õpilasi oma tegelikke kogemusi uurijatega jagama (Chalamandaris \& Piette, 2015). Õpilaste vastused koguti KiVa programmi andmebaasi Turu Ülikoolis, sealt edastati andmefail artikli autorile.

\section{Andmeanaliuiis}

Uuringu andmeanalüüs kavandati andmekogumise järel, arvestades kujunenud andmestiku võimalusi ja piiranguid. Kuigi andmeanalüüsi plaani koostamine andmekogumise järel võib ohustada tulemuste usaldusväärsust, kuna uurija võib teha kallutatud valikuid, ei olnud kohandamisprojekti tegevus- ja ajakava tõttu praegusel juhul võimalik teisiti toimida. Lähtudes klaster-RKKde andmeanalüüsile esitatud soovitustest (Higgins \& Green, 2011), tehti analüüsid koolide või gruppide tasandil. Kuna õpilased vastasid 
küsitlusele anonüümselt, ei olnud andmestikus võimalik jälgida muutusi indiviidi tasandil. Teine kitsendus puudutas 1. klassi õpilasi. Kuna baastasemeid mõõdeti 2013. aasta sügisel, mil 1. klassi lapsed olid alles kooliteed alustanud, jäeti nad vähese kollektiivikogemuse ja lugemisoskuse tõttu baastasemete hindamisest välja. Tulemuste vanuseliste erinevuste hindamisel käsitletakse 1. klassi õpilaste rühma eraldiseisvana.

Andmete analüüsimisel tehti esmalt kirjeldav analüüs ning anti ülevaade kiusajate ja ohvrite levimusest vanuserühmade ja õpilase soo lõikes baastasemel ning esimese ja teise õppeaasta lõpus nii katse- kui ka kontrollkoolides. Levimuse hindamiseks jagati õpilased OBVQ kahe küsimuse vastuste põhjal kiusajateks ja ohvriteks. Liigitamise lävendina kasutati vastusevarianti „2-3 korda kuus või sagedamini” (Solberg \& Olweus, 2003). Selle alusel toodi välja ohvrite ja kiusajate protsendid kõigi õpilaste hulgast. Ohvrite ja kiusajate levimuse väljaselgitamine võimaldab tõmmata paralleele mitme varasema sarnase uuringuga (nt Currie et al., 2012).

Koolide tasandi analüüsimiseks arvutati iga osaleva kooli näitajad kiusajate ja ohvrite osakaaludes. Nii nagu Hutchingsi ja Clarksoni (2015) uurimuses, hinnati ka praegusel juhul kooli tasandil toimunud muutusi sõltuvate valimite $t$-testiga. KiVa ja kontrollkoolide vaheliste erinevuste hindamiseks kasutati sõltumatute valimite $t$-testi. Uuringust väljalangenud koolide baastaseme näitajaid võrreldi uuringusse jäänute omadega, kasutades sõltumatute valimite $t$-testi. Programmi mõju kirjeldamiseks esitati levimuse näitajate põhjal KiVa ja kontrollgrupis kiusajaks ja ohvriks sattumise riskisuhted (odds ratio, OR).

\section{Tulemused}

\section{Kiusajate ja ohvrite levimus ning selle muutus kahe aasta jooksul KiVa ja kontrollkoolides}

Esmalt liigitati õpilased Solbergi ja Olweuse (2003) soovitatud lävendi põhjal kiusajateks ja ohvriteks. Tabelis 3 on esitatud kiusajate ja ohvrite protsendid KiVa ja kontrollgrupi ópilaste hulgas uuringu alguses ning esimese ja teise õppeaasta lõpus. 
Tabel 3. Kiusajate ja ohvrite levimus KiVa ja kontrollgrupis soo ja vanuserühmade kaupa kolmel mõõtmishetkel

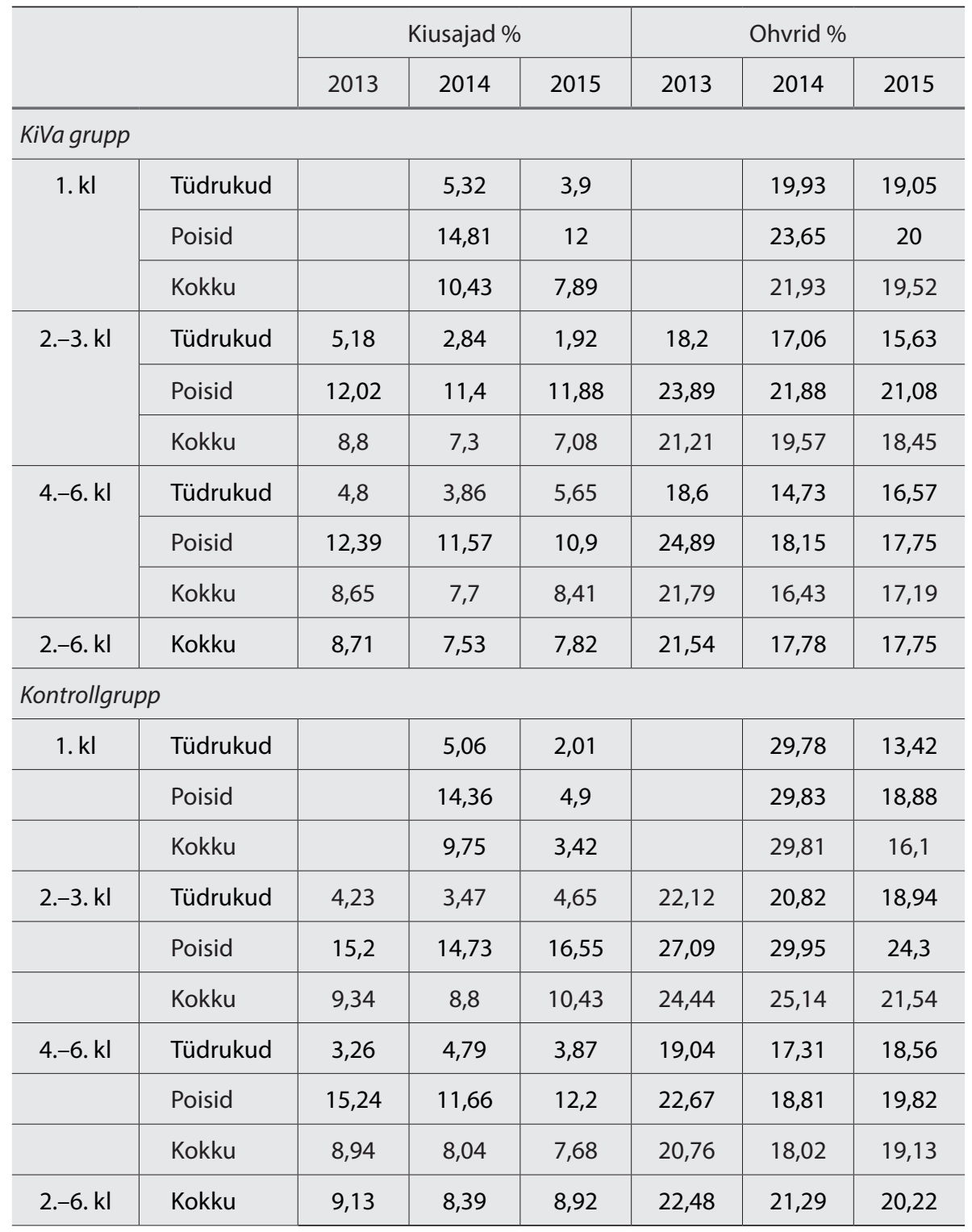

KiVa ja kontrollgrupi baastaseme tulemustest ilmnes, et keskmiselt kannatas kiusamise all 22\% õpilastest ja teisi kiusas 9\% õpilastest. Poiste hulgas oli kiusajaid ja ohvreid mõnevõrra rohkem kui tüdrukute hulgas ning seda nii KiVa kui ka kontrollgrupis ja eri vanuserühmades. Kiusajate ja ohvrite hulga vähenemist vanuserühmiti baastasemete põhjal välja ei joonistunud, küll aga vähenes KiVa koolide ohvrite hulk esimese õppeaasta lõpuks. Teise 
õppeaasta lõpus kogutud andmete põhjal võib KiVa koolide II astme klassides täheldada mõningast tagasilangust. Kolme mõõtmishetke lõikes avaldub KiVa koolides nii kiusajate kui ka ohvrite protsentides langustrend. Ka kontrollkoolide kiusajate levimust iseloomustab sarnane trend, kuid ohvrite protsendid olid langenud teise õppeaasta lõpuks oluliselt.

Klastri (kooli) tasandi analüüsimiseks arvutati iga kooli kohta kiusajate ja ohvrite protsent kõigil kolmel mõõtmishetkel (tabel 4).

Tabel 4. Kiusajate ja ohvrite keskmised protsendid KiVa ja kontrollkoolides ning muutuste suurus I ja II aasta lõpuks

\begin{tabular}{l|l|c|c|c|c|c}
\hline & & $\begin{array}{c}2013 \\
\text { sügis } \%\end{array}$ & $\begin{array}{c}2014 \\
\text { kevad } \%\end{array}$ & $\begin{array}{c}2015 \\
\text { kevad \% }\end{array}$ & $\begin{array}{c}\text { Muutus } \\
\text { I aasta } \\
\text { lõpuks \% }\end{array}$ & $\begin{array}{c}\text { Muutus } \\
\text { Il aasta } \\
\text { lõpuks \% }\end{array}$ \\
\hline Kiusajad & KiVa grupp & & 10,43 & 7,89 & & 24,3 \\
\hline 1. klass & Kontrollgrupp & & 9,75 & 3,42 & & 64,9 \\
\hline & KiVa grupp & 8,71 & 7,53 & 7,82 & 13,6 & $-3,9$ \\
\hline 2.-6. klass & Kontrollgrupp & 9,13 & 8,39 & 8,92 & 8,1 & $-6,3$ \\
\hline Ohvrid & & & & & & \\
\hline 1. klass & KiVa grupp & & 21,93 & 19,52 & & 11,0 \\
\hline & Kontrollgrupp & & 29,81 & 16,10 & & 46,0 \\
\hline 2.-6. klass & KiVa grupp & 21,54 & 17,78 & 17,75 & 17,5 & 0,2 \\
\hline & Kontrollgrupp & 22,48 & 21,29 & 20,22 & 5,3 & 5,0 \\
\hline
\end{tabular}

Märkus. I aasta muutuse hindamisse kaasati 20 KiVa ja 19 kontrollkooli, II aasta muutuse hindamisse võrdluses I aasta tasemega 17 KiVa ja 13 kontrollkooli.

Koolidega tehtud sõltuvate valimite $t$-test näitas olulist erinevust baastaseme ja I järelhindamise ning baastaseme ja II järelhindamise vahel ohvrite levimuses KiVa koolide 2.-6. klassides (vastavalt $t(19)=3,20, p=0,005$ ja $t(16)=2,84, p=0,01)$. Kiusajate sageduse põhjal olulist erinevust ei ilmnenud, kuigi täheldada võis esmalt 13,6\% langustrendi ja II aasta lõpuks väikest, kuid statistiliselt mitteolulist tõusutrendi. Kontrollkoolide 2.-6. klassides olid mõlema näitaja puhul erinevused statistiliselt mitteolulised. Seevastu kontrollkoolide 1. klassi õpilaste hulgas vähenes ohvrite ja kiusajate osakaal silmatorkavalt.

Sõltumatute valimite $t$-testiga hinnati KiVa ja kontrollkoolide puhul ohvrite ja kiusajate protsente igal mõõtmishetkel. KiVa koolides vähenes 
ohvrite protsent, mõningane vähenemine toimus ka kontrollkoolides. KiVa ja kontrollkoolide ohvrite ja kiusajate protsentide erinevused osutusid kooli tasandi analüüsis statistiliselt mitteoluliseks.

Uurimistulemuste põhjal tehti uuringust lahkunud ja uuringusse jäänud koolide võrdlev analüüs, lähtudes kiusajate ja ohvrite levimuse baastasemest. Sõltumatute valimite $t$-test koolide tasandil näitas, et nii KiVa kui ka kontrollkoolide grupist lahkunud koolide puhul ei erine kiusajate ja ohvrite protsendid statistiliselt oluliselt.

\section{KiVa programmi rakendamise võimalik mõju kiusamise näitajatele}

Et hinnata KiVa programmi rakendamise võimalikku mõju kiusajate ja ohvrite levimusele, arvutati OR 95\% usaldusvahemikega. Esmalt hinnati kiusajaks ja ohvriks sattumise riski esimese rakendamisaasta lõpus võrrelduna programmi rakendamise eelse seisuga. Uurimistulemustest ilmnes, et KiVa koolides langes ohvrite osakaal esimese õppeaasta jooksul 21,5\%lt 17,8\%le $(O R=1,27, p<0,001)$ ja kontrollkoolides $22,5 \%$ lt 21,3\%le $(O R=1,05$, ei ole statistiliselt oluline erinevus). Järgmisena hinnati KiVa ja kontrollkoolide kõrvutamisel saadud ORe (tulemused on esitatud tabelis 5). Need ORid väljendavad tõenäosust sattuda kiusamise ohvriks (kiusajaks) kontrollkoolides võrreldes tõenäosusega sattuda kiusamise ohvriks (kiusajaks) KiVa programmi rakendanud koolides.

Tabel 5. Ohvriks ja kiusajaks olemise riskisuhted kontrollkoolides võrrelduna KiVa koolidega KiVa programmi esimese ja teise katsetamisaasta lõpus

\begin{tabular}{l|c|c|c|c|c|c}
\hline & \multicolumn{3}{|c|}{ Ohver } & \multicolumn{3}{c}{ Kiusaja } \\
\cline { 2 - 7 } & OR & $95 \%$ Cl & $p$ & OR & $95 \%$ Cl & $p$ \\
\hline $\begin{array}{l}\text { 2014: kontrollkool - } \\
\text { KiVa kool, 1. kl }\end{array}$ & $\mathbf{1 , 5 1}$ & {$[1,13-2,03]$} & $\mathbf{0 , 0 0 6}$ & 0,93 & {$[0,60-1,43]$} & 0,73 \\
\hline $\begin{array}{l}\text { 2015: kontrollkool - } \\
\text { KiVa kool, 1. kl }\end{array}$ & 0,79 & {$[0,54-1,17]$} & 0,24 & 0,41 & {$[0,20-0,85]$} & 0,02 \\
\hline $\begin{array}{l}\text { 2014: kontrollkool - } \\
\text { KiVa kool, 2.-6. kl }\end{array}$ & 1,25 & {$[1,08-1,45]$} & $\mathbf{0 , 0 0 3}$ & 1,12 & {$[0,91-1,39]$} & 0,28 \\
\hline $\begin{array}{l}\text { 2015: kontrollkool - } \\
\text { KiVa kool, 2.-6. kl }\end{array}$ & 1,17 & {$[0,98-1,40]$} & 0,08 & 1,15 & {$[0,90-1,49]$} & 0,27 \\
\hline
\end{tabular}

Märkused. OR - riskisuhe; $\mathrm{Cl}$ - usaldusvahemik; $p$ - olulisuse nivoo. Olulised riskisuhted on esitatud poolpaksus kirjas. 
Uurimistulemustest ilmnes, et pärast esimest KiVa programmi rakendamise aastat oli KiVa koolide õpilastel oluliselt väiksem risk sattuda kiusamise ohvriks kui kontrollkoolide õpilastel (OR 2.-6. klassil: 1,25). Esimese klassi lastel puudus võrdlus baastasemega, kuid KiVa koolides oli kontrollkoolidega võrreldes esimese õppeaasta kevadel oluliselt väiksem kiusamise ohvriks sattumise risk ka 1. klassis (OR 1. klassil: 1,51). Teise õppeaasta lõpuks ei olnud KiVa ja kontrollkoolide riskisuhted enam oluliselt erinevad, kuna ka kontrollkoolides vähenes kiusajate ja ohvrite arv märkimisväärselt.

\section{Arutelu}

Uurimuse eesmärk oli klaster-RKK abil kirjeldada alles kohandatava KiVa kiusamisvastase programmi mõju kiusamise vähendamisele Eesti koolides kaheaastase katsetamisperioodi jooksul. Selleks hinnati uuringus osalevate koolide ohvrite ja kiusajate levimuse baastaseme näitajaid ning neis esinevaid soolisi ja vanuselisi erinevusi, seejärel võrreldi KiVa programmi katsetavate ja kontrollkoolide kiusamise näitajaid baastasemel ning aasta ja kaks aastat pärast programmiga alustamist. Kuna kontrollkatset alustati paralleelselt programmi kohandamise tegevustega, oli artikli autor valmis võimaluseks, et programmi elemente ei ole positiivse muutuse tekkeks veel piisavalt kohandatud.

\section{Kiusajate ja ohvrite levimuse baastase ning muutused KiVa ja kontrollkoolides}

Esmalt analüüsiti kiusajate ja ohvrite levimust mõlemas uuringugrupis. Kiusamise ohvrite ja kiusajate määratlemiseks kasutati Solbergi ja Olweuse (2003) soovitatud sagedushinnangu lävendit. Nii nagu varasemates uuringutes (nt Chester et al., 2015), oli ka praeguse uuringu puhul keskmiselt $22 \%$ õpilastest ohvri rollis ja 9\% kiusaja rollis. Kuigi ohvrite ja kiusajate protsendid on sarnased varasemates suurtes ja esinduslikes uuringutes saadud protsentidega, tuleb tulemuste üldistamisel kõigile Eesti koolidele siiski olla ettevaatlik - olgugi et uuringu indiviidide valim oli suur, kuulusid sinna selleks ise soovi avaldanud, mitte kõigi Eesti koolide hulgast juhuvaliku teel saadud koolid.

Uuringu disainiks valitud klaster-RKK eeldab, et koolide randomiseerimisel katse- ja kontrollgruppi on ideaaliks olukord, kus katse- ja kontrollgrupp ei erine üksteisest uuritava tunnuse baastaseme poolest (Chalamandaris \& Piette, 2015). Erinevalt RKK kvaliteeti puudutavatest soovitustest (Campbell et al., 2012) hinnati praeguses uuringus baastaset alles pärast 
randomiseerimist, kuid see võis piirata tulemuste usaldusväärsust, kuna teadlikkus oma kooli paigutumisest katse- või kontrollgruppi võis mõjutada vastamist. Lisaks lahkus kontrollgrupist üks suur kool juba enne baastaseme hindamist, mistõttu tekkis oht, et grupid pole enam tasakaalus. Siiski võib 2013. aasta baastaseme mõõtmise tulemuste põhjal väita, et KiVa ja kontrollkoolide vahel puudus kiusajate ja ohvrite protsentides statistiliselt oluline erinevus.

Craig ja tema kolleegid (2009) on 40 riigi kiusamisnäitajaid võrreldes täheldanud, et enamikus riikides raporteerivad poisid sagedasemat kiusamiskäitumist kui tüdrukud, seevastu ohvriks olemise sageduse poolest on soolised erinevused varieeruvamad. Sarnased erinevused korduvad ka krooniliste kiusajate ja ohvrite protsentides. Kooskõlas mitmete varasemate Eesti õpilasi käsitlenud uurimustega (Chester et al., 2015; Currie et al., 2012) ilmnes ka praegusel juhul, et poiste hulgas oli kiusajaid ja ohvreid mõnevõrra rohkem kui tüdrukute hulgas ning seda nii KiVa kui ka kontrollkoolides ja eri vanuserühmades.

Varasemad HBSC uurimused on näidanud õpilaste vanusega seotud selget langustrendi nii kiusajate kui ka ohvrite levimuses (Currie et al., 2012). Praeguses kontrollkatses kiusajate ja ohvrite arvu vähenemise trende baastasemetes vanuse alusel välja ei joonistunud, küll aga ilmnes, et eri vanuserühmades vähenes KiVa koolide ohvrite arv esimese õppeaasta lõpuks. Baastasemetel põhinevate trendide puudumine võib olla seletatav sellega, et kontrollkatse valimisse kuulunud õpilased olid nooremad kui HBSC valimi omad (7-11aastased vs. 11-15aastased). Mõõtevahendina kasutatud Olweuse kiusaja-ohvri küsimustiku sobivust noorematele õpilastele ei ole Eestis kontrollitud. Lisaks mõõdeti baastaset erandkorras õppeaasta alguses, mis võis tingida leebemad hinnangud just lühema koolikogemusega ja noorematelt õpilastelt.

Ohvrite protsent KiVa koolide 2.-6. klassi õpilaste baastaseme korral oli oluliselt kõrgem kui mõlemas järelhindamises, kusjuures 2014. ja 2015. aasta kevade tulemused omavahel oluliselt ei erinenud. Kuigi väga väheste programmide puhul on infot pikemaajalise mõju kohta ja saadaval rohkem kui ühe järelhindamise andmed (Farrington \& Ttofi, 2009), on oletatud, et kiusamine väheneb kõige enam just esimesel rakendamisaastal, seevastu järgnevatel aastatel võib täheldada väiksemat langustrendi või nn platoole püsima jäämist. Märkimisväärset langust esimesel aastal ja seejärel langustrendi jätkumist näitasid ka praeguse uurimuse KiVa koolide õpilaste tulemused. Kiusajate levimuses toimus samuti langus, kuid see ei olnud statistiliselt oluline. Selline tulemus erineb Soome RKK omast, kus ka kiusajate protsendi langus oli oluline või isegi suurem kui ohvrite oma (Kärnä et 
al., 2011b). Tulemustest nähtub, et Eestis kohandatud KiVa programm võimaldab kiiremini vähendada eelkõige kiusamise all kannatamise sagedust, seevastu kiusamiskäitumise oluline vähendamine võtab kauem aega või seisneb põhjus selles, et KiVa programmi kriitilisi osi pole veel kohandatud ega rakendatud. Samas tuleks toimunud langusi hinnates meeles pidada, et enne-pärast disainiga uuringutes võib esineda tulemuste regressioon keskmise suunas ja korduv testimine võib mõjutada tulemusi.

\section{Programmi mõju}

Et hinnata KiVa programmi rakendamise võimalikku mõju kiusajate ja ohvrite levimusele, arvutati riskisuhted (OR) 95\% usaldusvahemikega. Toetudes Soomes (Kärnä et al., 2011a, 2011b) ja Walesis (Hutchings \& Clarkson, 2015) saadud positiivsetele tulemustele, oletati, et Eesti koolide tarbeks kohandatud tuumtegevuste katsetamise tulemusena väheneb nii kiusajate kui ka ohvrite arv oluliselt juba esimese õppeaasta lõpuks ja langustrend jätkub teisel õppeaastal. Ohvrite levimus vähenes vaatlusalusel ajal tõepoolest oluliselt. Riskisuhe näitab, et KiVa programmi 8kuulise rakendamise järel oli õpilaste risk sattuda kiusamise ohvriks 1,27 korda väiksem. See tulemus on isegi mõnevõrra parem kui Kärnä jt (2011b) suures üleriigilises uuringus ilmnenud riskisuhe. KiVa koolides vähenes ohvrite osakaal esimese õppeaastaga $21,5 \%$ lt 17,8\%le, see on üle $17 \%$ vähenemine, mis on üsna lähedal Farringtoni ja Ttofi (2009) programmidega saavutatava muutuse keskmisele protsendile.

Pärast esimest KiVa programmi rakendamise aastat on KiVa koolide õpilastel oluliselt väiksem risk sattuda kiusamise ohvriks kui kontrollkoolide õpilastel (OR 2.-6. klassil: 1,25). Saadud riskisuhe on mõnevõrra parem kui Farringtoni ja Ttofi (2009) leitu: esitatud 44 programmi ülevaates oli randomiseeritud katsete keskmine 1,10. Kuna varasemate uurimistulemustega (nt Currie et al., 2012) võrreldes olid selles uurimuses I kooliastme korral ohvrite osakaalud sügisel mõnevõrra väiksemad, on praegusel juhul alust arvata, et küsitluse toimumise ajal (õppeaasta algul) alahindasid väiksemad lapsed enda kiusamise sagedust. Seega võiks eeldada ohvrite sageduse veelgi suuremat vähenemist esimesel katseaastal.

1. klassi õpilastelt baastaseme andmeid ei kogutud, mistõttu oli võimalik analüüsida üksnes erinevusi esimese ja teise katseaasta lõpus. Võib oletada, et KiVa koolide 1. klassides oli 2014. aasta kevadeks langus juba toimunud. Sellele viitab ka suur erinevus kiusajate ja ohvrite levimuses KiVa ja kontrollkoolide 1. klassi õpilaste hulgas 2014. aastal: KiVa koolides oli võrreldes kontrollkoolidega esimese õppeaasta kevadel 1,5 korda vähem kiusamise 
ohvreid. Selline tulemus võib peegeldada programmi rakendamise positiivset mõju, sest randomiseerimise eesmärgist lähtudes ei ole alust arvata, et KiVa ja kontrollkoolide 1. klassi õpilaste baastasemed oleksid olnud erinevad. Siiski tuleks seda tulemust järgmistes uuringutes baastaseme määramise abil täpsemalt kontrollida.

Ootuspärasest erinev tulemus ilmnes teise katseaasta lõpus: KiVa ja kontrollkoolide vahelised erinevused ja riskisuhted, mis olid seotud kiusajaks ja ohvriks sattumisega, ei olnud enam olulised. Esimestes klassides oli aga kiusamise all kannatamise erinevus lausa vastupidine - kontrollkoolide õpilaste tulemused olid KiVa koolide näitajatest halvemad. Selle tõenäoliseks põhjuseks on kontrollkoolides toimunud kiusajate ja ohvrite levimuse langus, mille mõjul kahanesid KiVa ja kontrollkoolide erinevused oluliselt. Kontrollgrupina kasutati KiVa programmi ootejärjekorras olevaid koole. Olukorra märgatavale paranemisele kontrollkoolides võisid teisel õppeaastal kaasa aidata just ettevalmistused KiVa programmi rakendamiseks järgneval õppeaastal, st tulemustes võis peegelduda programmi tegevuste levik kontrollgruppi ehk nn ülekandeefekt (spillover effect, Ferrer-Wreder et al., 2012). Kontrollkoolid ei tohtinud küll veel ametlikult programmi rakendada, kuid kooli meeskond oli esmase ettevalmistuse juba saanud ning õpetajad olid teadlikud, et uue õppeaasta algusest alustatakse intensiivsemat tööd kiusamise vähendamise nimel, ning nad võisid teha pingutusi positiivsema olukorra saavutamiseks. Ootuspärasest erineva tulemuse põhjuseks võib olla ka mõningane tagasilangus KiVa koolides. Nimelt võib teisel aastal - pärast väga intensiivset tegutsemist - olla keeruline jätkata koolis kvaliteetset programmi rakendamist. Kiusamisvastaste programmide puhul on täheldatud rakendamise mahust ja intensiivsusest tingitud efekti (Farrington \& Ttofi, 2009), mistõttu teise aasta „pohmell” võib tuua kaasa mõningase tagasilanguse.

\section{Uurimuse piirangud}

Klaster-RKK kasutamine on keeruline ülesanne iga uurija jaoks. Ka siinses uurimuses on mitmeid uuringu disainiga seotud piiranguid. Kuna uuring toimus pingelise ajakavaga KiVa programmi kohandamise ja katsetamise projekti raames, tuli artikli autoril teha disainis valikuid, mis ei ole kõige paremas kooskõlas klaster-RKKdele esitatavate nõuete ja soovitustega (Campbell et al., 2012; Higgins \& Green, 2011).

Tänu uuringu disainile ja klaster-RKK andmeanalüüsi ühikuks valitud randomiseerimisühikule oli pikilõikelisi andmeid võimalik kasutada klastri ehk kooli tasandi analüüsis, kuid valimi liikmete arv (39 esimesel ja 30 teisel 
katseaastal) oli oluliste tulemuste esiletulekuks väikesevõitu. Samas võimaldab andmete analüüsimine klastrite tasandil vältida sageli klaster-RKKdes esinevat analüüsiühiku viga (Higgins \& Green, 2011). Uuringusse kaasatud klastrite arv oli piiratud kohandamis- ja katsetamisprojekti ressurssidega ning selle moodustamisel ei saanud arvestada prognoositava valimi jõuga. Kuna uuring oli anonüümne, ei olnud võimalik rakendada selliseid analüüsimeetodeid, mis hindavad indiviidi tasandi muutusi pikilõikeliselt, ega analüüsida uuringust väljalangejaid indiviidi tasandil.

Erinevalt RKK soovituslikust disainist (Campbell et al., 2012) võeti lapsevanematelt informeeritud nõusolek ja koguti baastaseme andmed pärast randomiseerimist, mistõttu olid grupiliikmed baastaseme hindamise ajal teadlikud oma kooli allokatsioonist. Nõusoleku võtmine alles pärast randomiseerimist võib tuua kaasa vildaka valimi (selection bias). Vaatlusaluses uuringus olid keeldujate protsendid KiVa ja kontrollkoolide puhul siiski sarnased. Teine oht, mis on seotud allokatsioonist teadlikkusega, puudutab vildakat osalemist indiviidi tasandil (recruitment bias, Higgins \& Green, 2011). Seda ohtu suurendas asjaolu, et õpilasküsitlust aitasid läbi viia kooli grupikuuluvusest teadlikud õpetajad, kes võisid mõjutada laste ligipääsu uuringule või vastuseid.

Baastaseme hindamine pärast katse- või kontrollgrupi määramist lõi võimaluse klastrite (koolide) ja indiviidide väljalangevuseks pärast randomiseerimist, see aga ei võimaldanud enam andmeanalüüsis lähtuda intention-to-treat-põhimõttest ning võis vähendada tulemuste usaldusväärsust. Tulemuste usaldusväärsust silmas pidades oli oluline hinnata uuringust väljalangejate näitajaid. Uuringus loobus teisel katseaastal osalemast kolm KiVa kooli ja viis kontrollkooli. Lahkunud koolid ei erinenud jätkanud koolidest kiusajate ja ohvrite levimuse baastaseme poolest. Koolid lahkusid eri põhjustel. Kontrollkoolide hulgast lahkujad tegid seda ennekõike omal soovil. Võib oletada, et motivatsioon jätkata ootejärjekorras oleva kontrollkoolina oli mõnevõrra väiksem kui juba programmi kasutavatel koolidel. KiVa koolide hulgast väljalangejate puhul oli motivatsioon vähem tähtis tegur, kuna kolmest koolist kaks lahkusid uuringust koolireformist tingitud sulgemise või struktuurimuudatuse tõttu.

Klaster-RKKde üks kitsaskohti on baastaseme tasakaalutus (Higgins \& Green, 2011), kuna randomiseeritakse tavaliselt üsna väike hulk klastreid. Üks võimalus baastaseme tasakaalustamiseks on kasutada stratifitseeritud randomiseerimist, mida ka praegusel juhul tehti. Lisaks kontrolliti katsegruppide baastaseme näitajaid, kuid need ei erinenud oluliselt.

Piirangutest on oluline käsitleda Olweuse kiusaja-ohvri küsimustikuga seotut. OBWQd on varem edukalt kasutatud pigem vanemate õpilaste 
puhul (Solberg \& Olweus, 2003; HBSC uuringud), vähem on hinnatud selle sobilikkust noorematele õpilastele. Samas on Soome uuringutes demonstreeritud OBVQ kahe globaalse väite head konstruktvaliidsust ka nooremate õpilaste puhul (Kärnä et al., 2011a, 2011b). Et suurendada meetodi usaldusväärsust ja vähendada kiusamise mõistmise erinevusi, lähtuti uurimuses soovitusest esitada enne küsimusi detailne kiusamise definitsioon koos selgitustega selle kohta, mis ei ole kiusamine (Evans et al., 2014). Selleks kasutati kahte üldistatud küsimust kiusamise all kannatamise sageduse ja teiste kiusamise sageduse kohta, mida Solberg ja Olweus (2003) on pidanud piisavaks ja kasulikuks just kiusajate ja ohvrite levimuse määramisel. Samas toovad kriitikud välja, et ainult kahe üldise küsimuse põhjal ei saa tegelikult kiusamisest ülevaadet, sest kiusamise olemus on mitmetahuline ja kajastamata jäävad kiusamise eri vormid (Evans et al., 2014). Edaspidistes uuringutes tasub kasutusele võtta OBWQ detailsem versioon, mis võimaldab käsitleda kogemusi kiusamise liikide kaupa.

Veel üks oluline tulemuste üldistatavuse piirang tuleneb asjaolust, et prooviuuringu kontrollkatset alustati paralleelselt programmi kohandamisega. Seetõttu kannatas programmi rakendamise täielikkus (fidelity). Tõenduspõhiste programmide edukuse seisukohalt on rakendamise täielikkus kriitilise tähtsusega (Ferrer-Wreder et al., 2012). Et teha usaldusväärsemaid järeldusi KiVa kasulikkusest kiusamise vähendamisel Eesti koolides, tuleks korrata kontrollkatset lõpuni kohandatud programmiga ning uuel ja soovitatavalt suuremal valimil, samuti tuleks pöörata erilist tähelepanu programmi rakendamise täielikkusele ja kvaliteedile. Kordusuuringu kavandamisel on tähtis võtta arvesse ka kolmandat kontrollkatse tulemusi pisendavat kitsaskohta - baastaseme väljaselgitamise aega -, mis programmi kohandamise tempo tõttu jäi esimese katseaasta sügisesse. Korrektsemaid tulemusi annab nn sesoonset efekti arvestav baastaseme hindamine ja järelhindamine konkreetsel ajal õppeaasta jooksul, näiteks igal kevadel (Chalamandaris \& Piette, 2015).

\section{Uurimuse olulisus ja praktiline väärtus}

KiVa kiusamisvastase programmi prooviuuring klaster-RKK meetodil on üks esimesi omataolisi mõju-uuringuid, mis on keskendunud Eesti haridusvaldkonnas kasutatavatele sekkumisviisidele. Riiklik poliitika rõhutab üha enam vajadust kasutada ühiskondlike probleemide lahendamiseks tõenduspõhiseid tegevusi (vt nt Vägivalla ..., s.a) ja hinnata Eesti tarbeks kohandatud või siin väljatöötatud sekkumisviiside mõju. Mõju-uuringute kvaliteetseks läbiviimiseks on vaja aga koolitada pädevaid uurijaid. 
Hoolimata mitmetest piirangutest on siinne uurimus siiski oluline allikas, mis pakub teavet KiVa programmi jätkuva arendamise ja koolides rakendamise kohta. Tulemused olid mitme aspekti poolest kooskõlas varasemate uuringute tulemustega nii meil kui ka mujal. Samas on KiVa programmi mõjude kohta usaldusväärsemate otsustuste tegemiseks tarvis korraldada kordusuuring, mille disain peaks olema paremini kooskõlas klaster-RKKdele esitatavate nõuetega, võimaldades ennetada praeguseid kitsaskohti, ning milles rakendatakse juba tervikuna kohandatud programmi ja jälgitakse rakendamise usaldusväärsuse määra.

Kokkuvõtteks saab öelda, et Eesti koolidel seisab ees tõsine katsumus, kui soovime, et meie lapsed saaksid areneda ja õppida tervislikus ja turvalises keskkonnas. Iga Eesti oludele sobilik kiusamisvastane programm on siin abiks. Siinne uurimus pakub ülevaadet KiVa kiusamisvastase programmi kohandamisest ja esmasest katsetamisest Eestis. Tulemused on lootustandvad - ainuüksi 8kuuse rakendamise järel saavutati kiusamise all kannatavate õpilaste arvu oluline, üle 17\% vähenemine. Tervikliku programmi kohandamine on pidev protsess, samuti vajab iga tõenduspõhine programm selle rakendamist toetavat ja tulemuslikkust hindavat süsteemi (Blueprints Programs, s.a), mis pole Eestis veel täielikult välja kujunenud.

\section{Tänusõnad}

KiVa kiusamisvastase programmi kohandamise ja katsetamise projekt aastatel 2013-2015 sai võimalikuks tänu haridus- ja teadusministeeriumi, siseministeeriumi, Briti saatkonna, hasartmängumaksu nõukogu, Kodanikuühiskonna Sihtkapitali, pro-bono partnerite ja eraisikutest annetajate toetusele. Tänuavaldused lähevad Birgit Rootsile, kes oli abiks uurigu käivitamisel, ja Krista Uibule, kes pakkus tuge käsikirja koostamisel.

\section{Huvide deklaratsioon}

Kristiina Treial on SA Kiusamisvaba Kool asutajaliige, nõukogu esimees (2012-2015) ja juhatuse liige (2015-2016).

\section{Kasutatud kirjandus}

Arseneault, L., Bowes, L., \& Shakoor, S. (2010). Bullying victimization in youths and mental health problems: 'Much ado about nothing'? Psychological Medicine, 40(5), 717-729. doi: http://dx.doi.org/10.1017/S0033291709991383 
Blueprints Programs (s.a). Retrieved from http://www.blueprintsprograms.com/criteria.

Campbell, M. K., Piaggio, G., Elbourne, D. R., \& Altman, D. G. (2012). Consort 2010 statement: Extension to cluster randomised trials. British Medical Journal, 345, 19-22. doi: http://dx.doi.org/10.1136/bmj.e5661

Castro, F. G., Barrera Jr, M., \& Holleran Steiker, L. K. (2010). Issues and challenges in the design of culturally adapted evidence-based interventions. Annual Review of Clinical Psychology, 6, 213-239. doi: http://dx.doi.org/10.1146/annurev-clinpsy-033109-132032

Chalamandaris, A.-G., \& Piette, D. (2015). School-based anti-bullying interventions: Systematic review of the methodology to assess their effectiveness. Aggression and Violent Behavior, 24, 131-174. doi: http://dx.doi.org/10.1016/j.avb.2015.04.004

Chester, K. L., Callaghan, M., Cosma, A., Donnelly, P., Craig, W., Walsh, S., \& Molcho, M. (2015). Cross-national time trends in bullying victimization in 33 countries among children aged 11, 13 and 15 from 2002 to 2010. The European Journal of Public Health, 25(2), 61-64.

doi: http://dx.doi.org/10.1093/eurpub/ckv029

Craig, W., Harel-Fisch, Y., Fogel-Grinvald, H., Dostaler, S., Hetland, J., SimonsMorton, B., ... Pickett, W. (2009). A cross-national profile of bullying and victimization among adolescents in 40 countries. International Journal of Public Health, 54(2), 216-224. doi: http://dx.doi.org/10.1007/s00038-009-5413-9

Currie, C., Zanotti, C., Morgan, A., Currie, D., De Looze, M., Roberts, C., ... Barnekow, V. (Eds.) (2012). Social determinants of health and well-being among young people. Health behaviour in school-aged children (HBSC): International report from the 2009/2010 survey. Health Policy for Children and Adolescents, 6. Retrieved from http://www.euro.who.int/_data/assets/pdf_file/0007/167281/ E96444_part1.pdf?ua=1.

Evans, C. B. R., Fraser, M. W., \& Cotter, K. L. (2014). The effectiveness of schoolbased bullying prevention programs: A systematic review. Aggression and Violent Behavior, 19(5), 532-544. doi: http://dx.doi.org/10.1016/j.avb.2014.07.004

Evans, C. B., \& Smokowski, P. R. (2015). Theoretical explanations for bullying in school: How ecological processes propagate perpetration and victimization. Child and Adolescent Social Work Journal, 33(4), 365-375. doi: http://dx.doi.org/10.1007/s10560-015-0432-2

Farrington, D. P., \& Ttofi, M. M. (2009). School-based programs to reduce bullying and victimization. Campbell Systematic Reviews, 6. Retrieved from http://www.campbellcollaboration.org/lib/download/718/. doi: http://dx.doi.org/10.4073/csr.2009.6

Ferrer-Wreder, L., Sundell, K., \& Mansoory, S. (2012). Tinkering with perfection: Theory development in the intervention cultural adaptation field. Child \& Youth Care Forum, 41(2), 149-171. doi: http://dx.doi.org/10.1007/s10566-011-9162-6

Fixsen, D. L., Naoom, S. F., Blase, K. A., Friedman, R. M., \& Wallace, F. (2005). Implementation research: A synthesis of the literature. Retrieved from http://citeseerx.ist. psu.edu/viewdoc/download;jsessionid=57E2303B987C49E8F088FEF1F33ABB7C ?doi=10.1.1.610.6226\&rep=rep1\&type $=$ pdf. 
Garandeau, C. F., Poskiparta, E., \& Salmivalli, C. (2014). Tackling acute cases of school bullying in the KiVa anti-bullying program: A comparison of two approaches. Journal of Abnormal Child Psychology, 42(6), 981-991. doi: http://dx.doi.org/10.1007/s10802-014-9861-1

Hawker, D. S., \& Boulton, M. J. (2000). Twenty years' research on peer victimization and psychosocial maladjustment: A meta-analytic review of cross-sectional studies. Journal of Child Psychology and Psychiatry, 41(4), 441-455. doi: http://dx.doi.org/10.1111/1469-7610.00629

Higgins, J. P. T., \& Green S. (2011). Cochrane handbook for systematic reviews of interventions. Version 5.1.0. The Cochrane Collaboration. Retrieved from http://www.cochrane-handbook.org.

Hodgins, M. (2008). Taking a health promotion approach to the problem of bullying. International Journal of Psychology and Psychological Therapy, 8(1), 13-23.

Hutchings, J., \& Clarkson, S. (2015). Introducing and piloting the KiVa bullying prevention programme in the UK. Educational \& Child Psychology, 32(1), 49-61.

Katz, J., Wandersman, A., Goodman, R. M., Griffin, S., Wilson, D. K., \& Schillaci, M. (2013). Updating the FORECAST formative evaluation approach and some implications for ameliorating theory failure, implementation failure, and evaluation failure. Evaluation and Program Planning, 39, 42-50. doi: http://dx.doi.org/10.1016/j.evalprogplan.2013.03.001

Kiusamisvaba Kool (s.a). Külastatud aadressil http://www.kivaprogram.net/estonia.

KiVa International (s.a). Retrieved from http://www.kivaprogram.net/.

Kõiv, K. (2006). Kiusamiskäitumise mitu tahku: ópilastevaheline kiusamine, õpilaste kiusamine õpetajate poolt, õpetajate kiusamine ópilaste poolt ning ópetajate kiusamine kooli personali ja lapsevanemate poolt. Tartu: Vali Press.

Kõiv, K. (2009). Bullying among Estonian pupils: An overview. In J. Mikk, M. Veisson, \& P. Luik (Eds.), Teenagers in Estonia: Values and behaviour. Estonian studies in education (Vol. 1, pp. 103-123). Frankfurt am Main etc.: Peter Lang.

Kärnä, A., Voeten, M., Little, T. D., Poskiparta, E., Kaljonen, A., \& Salmivalli, C. (2011a). A large-scale evaluation of the KiVa antibullying program: Grades 4-6. Child Development, 82(1), 311-330.

doi: http://dx.doi.org/10.1111/j.1467-8624.2010.01557.x

Kärnä, A., Voeten, M., Little, T. D., Poskiparta, E., Alanen, E., \& Salmivalli, C. (2011b). Going to scale: A nonrandomized nationwide trial of the KiVa antibullying program for grades 1-9. Journal of Consulting and Clinical Psychology, 79(6), 796-805. doi: http://dx.doi.org/10.1037/a0025740

Merrell, K. W., Gueldner, B. A., Ross, S. W., \& Isava, D. M. (2008). How effective are school bullying intervention programs? A meta-analysis of intervention research. School Psychology Quarterly, 23(1), 26-42. doi: http://dx.doi.org/10.1037/1045-3830.23.1.26

Nakamoto, J., \& Schwartz, D. (2010). Is peer victimization associated with academic achievement? A meta-analytic review. Social Development, 19(2), 221-242. doi: http://dx.doi.org/10.1111/j.1467-9507.2009.00539.x

Nocentini, A., Menesini, E., \& Salmivalli, C. (2013). Level and change of bullying behavior during high school: A multilevel growth curve analysis. Journal of Adolescence, 36(3), 495-505. doi: http://dx.doi.org/10.1016/j.adolescence.2013.02.004 
Olweus, D. (1993). Bullying at school: What we know and we can do. Oxford: Blackwell.

Olweus, D. (2013). School bullying: Development and some important challenges. Annual Review of Clinical Psychology, 9, 751-780. doi: http://dx.doi.org/10.1146/annurev-clinpsy-050212-185516

Põhikooli- ja gümnaasiumiseadus (2010). Riigi Teataja I, 16.06.2016, 8. Külastatud aadressil https://www.riigiteataja.ee/akt/13332410?leiaKehtiv.

Rigby, K., \& Smith, P. K. (2011). Is school bullying really on the rise? Social Psychology of Education, 14(4), 441-455. doi: http://dx.doi.org/10.1007/s11218-011-9158-y

Rivers, I., Poteat, V. P., Noret, N., \& Ashurst, N. (2009). Observing bullying at school: The mental health implications of witness status. School Psychology Quarterly, 24(4), 211-223. doi: http://dx.doi.org/10.1037/a0018164

Saarento, S., Boulton, A. J., \& Salmivalli, C. (2015). Reducing bullying and victimization: Student- and classroom-level mechanisms of change. Journal of Abnormal Child Psychology, 43(1), 61-76. doi: http://dx.doi.org/10.1007/s10802-013-9841-x

Saarento, S., Kärnä, A., Hodges, E. V., \& Salmivalli, C. (2013). Student-, classroom-, and school-level risk factors for victimization. Journal of School Psychology, 51(3), 421-434. doi: http://dx.doi.org/10.1016/j.jsp.2013.02.002

Saarento, S., \& Salmivalli, C. (2015). The role of classroom peer ecology and bystanders' responses in bullying. Child Development Perspectives, 9(4), 201-205. doi: http://dx.doi.org/10.1111/cdep.12140

Sainio, M., Veenstra, R., Huitsing, G., \& Salmivalli, C. (2010). Victims and their defenders: A dyadic approach. International Journal of Behavioral Development, 35(2), 144-151. doi: http://dx.doi.org/10.1177/0165025410378068

Salmivalli, C. (2014). Participant roles in bullying: How can peer bystanders be utilized in interventions? Theory into Practice, 53(4), 286-292.

doi: http://dx.doi.org/10.1080/00405841.2014.947222

Salmivalli, C., Lagerspetz, K., Björkqvist, K., Österman, K., \& Kaukiainen, A. (1996). Bullying as a group process: Participant roles and their relations to social status within the group. Aggressive Behavior, 22(1), 1-15.

doi: http://dx.doi.org/10.1002/(SICI)1098-2337(1996)22:1<1::AID-AB1>3.0.CO;2-T

Salmivalli, C., \& Poskiparta, E. (2012a). KiVa antibullying program: Overview of evaluation studies based on a randomized controlled trial and national rollout in Finland. International Journal of Conflict and Violence, 6(2), 294-302.

Salmivalli, C., \& Poskiparta, E. (2012b). Making bullying prevention a priority in Finnish schools: The KiVa antibullying program. New Directions for Youth Development, 2012(133), 41-53. doi: http://dx.doi.org/10.1002/yd.20006

Solberg, M. E., \& Olweus, D. (2003). Prevalence estimation of school bullying with the Olweus Bully/Victim Questionnaire. Aggressive Behavior, 29(3), 239-268. doi: http://dx.doi.org/10.1002/ab.10047

Sourander, A., Jensen, P., Rönning, J. A., Niemelä, S., Helenius, H., Sillanmäki, L., ... Almqvist, F. (2007). What is the early adulthood outcome of boys who bully or are bullied in childhood? The Finnish "From a boy to a man" study. Pediatrics, 120(2), 397-404. doi: http://dx.doi.org/10.1542/peds.2006-2704 
Ttofi, M. M., \& Farrington, D. P. (2011). Effectiveness of school-based programs to reduce bullying: A systematic and meta-analytic review. Journal of Experimental Criminology, 7(1), 27-56. doi: http://dx.doi.org/10.1007/s11292-010-9109-1 doi: http://dx.doi.org/10.1016/j.appdev.2014.11.005

Volk, A. A., Dane, A. V., \& Marini, Z. A. (2014). What is bullying? A theoretical redefinition. Developmental Review, 34(4), 327-343. doi: http://dx.doi.org/10.1016/j.dr.2014.09.001

Vägivalla ennetamise strateegia aastateks 2015-2020 (2015). Külastatud aadressil http://www.kriminaalpoliitika.ee/et/vagivalla-vahendamise-arengukava/vagivallaennetamise-strateegia-2015-2020.

Yeager, D. S., Fong, C. J., Lee, H. Y., \& Espelage, D. L. (2015). Declines in efficacy of anti-bullying programs among older adolescents: Theory and a three-level metaanalysis. Journal of Applied Developmental Psychology, 37, 36-51. 


\title{
KiVa anti-bullying programme in Estonia - the results from a two year cluster-randomised pilot trial
}

\author{
Kristiina Treial $^{\mathrm{a} 1}$ \\ ${ }^{a}$ University of Tartu, Institute of Education
}

\section{Summary}

\section{Introduction}

Bullying is defined as repeated and intentional aggressive behaviour against a victim who cannot readily defend him/herself (Olweus 1993, 2013). Bullying and victimisation in schools is a widespread and universal problem seriously threatening students' mental and social health (Arseneault et al., 2010; Hawker \& Boulton, 2000), impairing their academic achievements and increasing the risk of school drop-out (Nakamoto \& Schwartz, 2010). Several negative long-term effects for victims as well as bullies have been determined (Olweus, 2013). Bullying can also negatively affect bystanders' mental health by merely observing the victimisation of their peers (Rivers et al., 2009).

Schools have an obligation (Põhikooli..., 2010) and the need to reduce bullying. The most effective ways to combat bullying are the evidence based whole school programmes (Evans et al., 2014; Farrington \& Ttofi, 2009; Ttofi \& Farrington, 2011). There are still numerous initiatives and programmes available with varying and questionable effectiveness (Salmivalli \& Poskiparta, 2012a). When compared with other European countries, Estonia's bullying and victimisation rates are remarkably high, with more than $20 \%$ of students suffering from chronic victimisation (Chester et al., 2015; Craig et al., 2009; Currie et al., 2012). Although much has been done in the field of bullying research (see Kõiv, 2009 for overview), there has been no evidence-based whole-school anti-bullying programmes in Estonia.

KiVa anti-bullying programme has been developed in Turku University, Finland and its effects and effectiveness has been evaluated with large scale randomised controlled trials and a national roll-out trial (Kärnä et al., 2011a, 2011b; Salmivalli \& Poskiparta, 2012a). The KiVa programme relies on participant roles approach to bullying (Salmivalli, 2014; Salmivalli et al., 
1996) and includes a variety of practices for the prevention of bullying, tackling bullying cases that arise and require attention, and minimising the negative effects of bullying and victimisation (see more Salmivalli \& Poskiparta, 2012b; KiVa International, s.a.). In 2012, the Foundation Against Bullying was formed in Estonia, and the adaptation of KiVa anti-bullying programme was started (see Kiusamisvaba Kool, s.a.). In parallel with the adaptation processes a preliminary evaluation was conducted.

The aim of this paper was to introduce the adaptation and the results of the first cluster-randomised controlled trial (henceforth cluster-RCT) of the KiVa anti-bullying programme in Estonian schools from 2013-2015. In line with the positive results from Finland (see Salmivalli \& Poskiparta, 2012a) and Wales (Hutchings \& Clarkson, 2015) a reduction in school-level self-reported prevalence of victims and bullies was expected. At the same time researchers were conscious of not getting any significant effects since the programme components were adapted in parallel to the trial, and it was likely that implementation fidelity might have been compromised because of that (Ferrer-Wreder et al., 2012). Furthermore, the larger adaptation project limited the number of schools in the intervention group and dictated the timetable of cluster-RCT design phases. Still, the trial was an important indicator in understanding what further adaptations and modifications were required to the programme.

\section{Method}

All schools where studies were carried out in Estonian and which had students at least from Grade 1 to Grade 6 (11-year old, 473 schools) were sent an information letter with an invitation to apply for the pilot trial. All 84 volunteering schools were stratified by school size into 4 groups and from each group 5 schools were blindly drawn by a research assistant into program-group and wait-list control-group. One control-school dropped out before the baseline assessment, resulting in a sample of $20 \mathrm{KiVa}$ and 19 control schools from all over Estonia. The prevalence of bullies and victims were assessed with two global self-reporting items from the Olweus BullyVictim Questionnaire (OBVQ, Kärnä et al., 2011a; Olweus, 2013; Solberg \& Olweus, 2003). The trial included three computer based data collections: a baseline assessment in autumn 2013 (5090 students from Grades 2 to 6), with a first follow-up assessment in spring 2014 (5162 students from Grades 2 to 6, plus 652 from Grade 1), and a second follow-up in spring 2015 (3537 students from Grades 2 to 6, plus 456 from Grade 1). Students completed the anonymous questionnaires via computer during normal school hours. 
All students could participate unless a clear parental refusal was received by an informed consent letter. An opt-out consent procedure was chosen for keeping the sample as representative as possible. Differently from recommendations to high quality RCT-s (Campbell et al., 2012), the randomisation was implemented before informed consent procedure and baseline assessment. Since the longitudinal data was anonymous and individual changes in bullying and victimisation could not be observed, the school level analyses were conducted by assessing group differences and changes in prevalence. To assess program effects the group level OR-s were calculated.

\section{Results}

Prevalence of bullies and victims determined by student self-reported bullying and victimisation frequencies with criterion of frequencies " $2-3$ times" or more recommended by Solberg \& Olweus (2003), were included into analysis. In line with previous research (e.g. Chester et al., 2015; Currie et al., 2012) the average baseline prevalence of victims was $22 \%$ and bullies 9\%. This differs from Currie et al. (2012) where no clear age-related trends in reduction of bullying and victimisation rates were visible. Previously the age-related trends have been shown in older samples of Estonian students (e.g. Currie et al., 2012), there is no available data regarding primary school students. Baseline data for KiVa- and control-schools were similar.

The results from follow-up assessments showed significant reductions in victimisation after the first 8 months of the programme's implementation when compared to baseline and to the control group as well. The average prevalence of victims in KiVa-schools dropped from $21.5 \%$ to $17,8 \%$ resulting in an average $17 \%$ reduction. The odds ratio (OR) of being victimised after the first program year compared to the previous situation was 1.27, $\mathrm{p}<.001$. This is similar to the OR demonstrated by Kärnä et al., 2011b in the Finnish national rollout trial. The second year follow-up results did not differ significantly from the first follow-up levels. When compared to control-schools, the risk of being victimised after the first trial year was significantly higher in control-group $(\mathrm{OR}=1.25, \mathrm{p}<.01)$. No significant difference in bullying emerged. Results of the second follow-up showed a significant drop in bullying and victimisation which was visible also in control-group. This may be due to programme dissemination (spillover effect) to control-schools since they were in wait-list condition, very motivated to confront bullying, and their preparation for implementing KiVa had already started in spring 2015, before the second follow-up assessment. 


\section{Limitations}

Besides the possible spillover effects (dissemination of program practises into control-group) several other issues need attention. Limitations arise when deviations are made to current study design from standard quality recommendations of RCTs (Campbell et al., 2012). Namely the randomisation before the informed consent collection procedure and baseline assessment may cause recruitment bias (Higgins \& Green, 2011). In longitudinal design the selective attrition of participants is a risk to validity (e.g. Chalamandaris \& Piette, 2015), in this study one control school withdrew from participation after randomisation and before baseline assessment, therefore no information about it's bullying data is available. In the present trial three schools which dropped out from KiVa group showed no difference from others, the reasons for leaving were related to school reforms; for five leaving schools from control group motivational issues may be relevant. Some methodological challenges are related to the validity of Olweus Bully-Victim Questionnaire global items for younger students. Relevant analysis in Estonia is needed, but OBVQ has been frequently used with older students, and in Finnish studies the good construct validity also for younger students has been demonstrated (Kärnä et al., 2011a, 2011b). Also a thorough explanation of bullying was presented before items as recommended by Evans and colleagues (2014). In data analysis the clustering was considered and unit-of-analysis error avoided by conducting cluster-level analyses.

The results presented here are from the pilot cluster-RCT. This clusterRCT is one of the first RCT-s in the Estonian educational field contributing significantly to practical decisions about anti-bullying interventions, and helping to raise the competence of conducting RCT-s in educational settings. For more robust assessment of KiVa program effectiveness in Estonia new RCT is needed in accordance with RCT guidelines, with larger samples, a full programme adapted and special attention to the implementation fidelity (Ferrer-Wreder et al., 2012). The system of providing KiVa and supporting it's implementation fidelity in schools is still under development. Every year new schools adapt KiVa and the research continues.

Keywords: school bullying, bully, victim, evidence based anti-bullying programme, randomised controlled trial 